\title{
GAMBARAN KESEHATAN MENTAL GURU SEKOLAH DASAR (SD) INKLUSI DI PEKANBARU
}

\author{
${ }^{1}$ Cut Aathirah Nurrady, ${ }^{2}$ Juliarni Siregar \\ 12 Fakultas Psikologi, Universitas Islam Riau, Indonesia. \\ ${ }^{1}$ Corresponding Author: Caathirahnurrady@yahoo.co.id
}

\begin{abstract}
The mental health of an inclusive teacher must be considered, because the demands of an inclusive SD teacher have more challenges such as lack of facilities to teach child with dissability, lack of knowledge about child with dissability that affects the mental condition of an inclusive SD teacher. This study aims to determine how the mental health picture of elementary school (SD) inclusion teachers in Pekanbaru. Subjects in this study were 182 teachers selected using cluster sampling. This study uses the Mental Health Inventory scale (MHI-38) compiled by Viet and Ware (1983) and adapted by Faizah and Amnah (2007). The analysis used is descriptive statistical analysis. The results of this study indicate the mental health of inclusive elementary school teachers in Pekanbaru is mostly in the medium category of $42.3 \%$, meaning that most of the inclusive elementary school teachers have mental health that is neither high nor low either. The majority of psychological well-being and psychological distress are in the moderate category. When viewed from the age, length of teaching, and the work status of teachers it was found that there were no significant mental health differences, where the mental health of teachers tended to be moderate.
\end{abstract}

Keywords: mental health, teachers, inclusive schools, Psychological WellBeing, Psychological Distress

\begin{abstract}
ABSTRAK
Kesehatan mental seorang guru inklusi harus diperhatikan, karena tuntutan seorang guru SD inklusi memiliki tantangan lebih seperti kurangnya fasilitas untuk mengajar $A B K$, kurangnya pengetahuan tentang $A B K$ yang mempengaruhi kondisi mental seorang guru SD inklusi. Penelitian ini bertujuan untuk mengetahui bagaimana gambaran kesehatan mental guru sekolah dasar (SD) inklusi di Pekanbaru. Subjek dalam penelitian ini sebanyak 182 orang guru yang dipilih menggunakan Cluster sampling. Penelitian ini menggunakan skala Mental Health Inventory (MHI-38) yang disusun oleh Viet dan Ware (1983) dan diadaptasi oleh Faizah dan Amnah (2007). Analisis yang digunakan yaitu analisis statistik deskriptif. Hasil dari penelitian ini menunjukkan kesehatan mental guru SD inklusi di Pekanbaru sebagian besar berada pada ketegori sedang yaitu $42,3 \%$, artinya sebagian besar guru SD inklusi memiliki kesehatan mental yang tidak tinggi dan tidak rendah juga. Psychological well-being dan psychological distress guru juga mayoritas berada pada kategori sedang. Jika ditinjau dari usia, lama mengajar, dan status kerja guru ditemukan bahwa tidak ada perbedaan kesehatan mental yang signifikan, dimana kesehatan mental guru cenderung sedang.
\end{abstract}

Kata Kunci: kesehatan mental, guru, sekolah inklusi, Psychological Well-Being, Psychological Distress. 


\section{PENDAHULUAN}

Jumlah Anak Berkebutuhan Khusus (ABK) di Provinsi Riau mengalami peningkatan yang signifikan sejak tahun 2007 sampai dengan tahun 2018. Pada tahun 2007 ABK yang terdaftar di sekolah berjumlah 200 orang. Pada tahun 2018 jumlah ABK mengalami peningkatan sebanyak 5 kali lipat sehingga jumlah $A B K$ yang terdaftar di sekolah berjumlah 1.034 orang (Dinas Pendidikan Provinsi Riau, 2018).

ABK yang ada di Indonesia memiliki hak dalam mendapatkan fasilitas pendidikan yang didukung oleh Undang-Undang Dasar 1945 pasal 31 ayat 1 dan 2 yang menyatakan seluruh warga Negara Indonesia berhak dan wajib mendapat pendidikan. Anak berkebutuhan khusus juga berhak mendapatkan pendidikan yang diatur dalam Undang-Undang No.20 Tahun 2003 ayat 2 yang menyatakan bahwa warga Negara yang memiliki kelainan fisik, emosional, mental, intelektual dan sosial berhak memperoleh pendidikan khusus (Garnida, 2015).

Sistem pendidikan ABK adalah untuk mempersiapkan mereka dapat berinteraksi sosial secara mandiri di masyarakat dan sekitarnya. Namun kenyataan yang ada di masyarakat sistem pendidikan SLB atau segregasi justru dipisahkan dengan lingkungannya. Menurut Budiyanto (dalam Garnida, 2015), sistem segregasi tidak mampu lagi menjalankan misi utama pendidikan, yaitu pendidikan yang memanusiakan manusia. Sistem segregasi cenderung diskriminatif, mahal, tidak efektif dan efesien, dan eklusif. Reynolds dan Birch (dalam Garnida, 2015) menyatakan juga bahwa model segregasi tidak menjamin kesempatan anak berkelainan atau ABK untuk mengembangkan potensinya secara optimal, karena kurikulum dirancang berdeda dengan kurikulum di sekolah biasa (umum).

Pendidikan inklusi merupakan perkembangan pendidikan yang terkini dari model pendidikan bagi anak berkelainan. Pendidikan inklusi secara formal ditegaskan dalam pernyataan tentang pendidikan khusus tahun 1994 yang menyatakan bahwa "prinsip mendasar pendidikan inklusi adalah, selama memungkinkan semua anak sebaiknya belajar bersama-sama tanpa memandang kesulitan ataupun perbedaan yang mungkin ada pada mereka" (Garnida, 2015).

Sejalan dengan penjelasan pendidikan untuk anak berkelainan atau $A B K$, yang menjelaskan bahwa ABK berhak mendapatkan pendidikan. pemerintah Indonesia mengembangkan program pendidikan untuk anak berkelainan atau ABK pada tahun 2000 dengan memunculkan sekolah inklusi, dimana program ini bertujuan untuk melanjutkan program pendidikan terpadu di Indonesia. Khususnya Pemerintah kota Pekanbaru melalui persetujuan Wali Kota Pekanbaru mengeluarkan Surat Keputusan (SK) yang menunjuk 37 sekolah dari jenjang SD sampai SMP sebagai sekolah inklusi kota Pekanbaru yang tersebar di beberapa kecamatan yang ada di kota Pekanbaru. Sekolah Dasar (SD) inklusi yang ada di Pekanbaru berjumlah 24 sekolah, baik sekolah Negeri maupun sekolah Swasta (SK Walikota, Dinas Pendidikan Kota Pekanbaru, 2017).

Ditunjukknya beberapa sekolah menjadi sekolah inklusi tentunya bukan hal yang mudah. Sekolah inklusi harus menyediakan kondisi kelas yang hangat, ramah, menerima keanekaragaman dan menghargai perbedaan dengan menerapkan kurikulum dan pembelajaran yang interaktif. Namun sekolah inklusi di Indonesia masih belum memenuhi fasilitas sarana seperti contohnya kamar mandi khusus untuk $A B K$ dan jalan jalur khusus untuk beraktifitas di lingkungan sekolah misalnya $A B K$ yang harus mengguanakan kursi roda (Ahsan, 2017). Guru dituntut melakukan kolaborasi dengan profesi atau sumberdaya manusia lain dalam perencanaan, pelaksanaan, dan evaluasi. Guru dituntut melibatkan orang tua secara bermakna dalam proses pendidikan. Guru yang nanti akan jadi Guru Pembimbing Khusus (GPK) harus mendapatkan pelatihan bagaimana menjalankan sekolah inklusi. GPK harus mendapatkan pelatihan teknis memfasilitasi anak ABK. Melakukan asesmen di sekolah untuk mengetahui ABK dan tindakan yang diperlukan. 
Mengadakan bimbingan khusus untuk kesepakatan dengan orang tua ABK. Mengidentifikasi hambatan berkait dengan kelainan fisik, social, dan maslah lainnya terhadap akses dan pembelajaran (Garnida, 2015).

Berdasarkan hasil wawancara yang dilakukan Kepada kepala Sekolah Dasar Negeri $X$ Pekanbaru yang menyatakan bahwa sekolah nya menjadi sekolah inklusi pada tahun 2017 yang ditetapkan oleh Wali Kota Pekanbaru. Guru-guru yang mengajar di sekolah tersebut sudah mendapatkan pelatihan mengenai sekolah inklusi dan $\mathrm{ABK}$, namun untuk fasilitas yang diberikan oleh pemerintah belum didapatkan hingga sekarang seperti Guru Pendamping Khusus (GPK), dan fasiitas untuk belajar juga belum memadai. Hal ini sejalan dengan penelitain yang dilakukan oleh Tarnoto (2016) dengan hasil bahwa berbagai permasalahan dalam kesiapan guru seperti kurangnya kompetensi guru dalam menghadapi $A B K$, banyaknya siswa ABK dalam satu kelas dan kurangnya kerja sama dari pihak masyarakat, ahli professional dan pemerintah.Wawancara kepada kepala Sekolah Dasar $Y$ Pekanbaru yang menyatakan bahwa sekolah nya telah menjadi sekolah inklusi pada tahun 2017 dan telah memberikan pelatihan kepada guru tentang $A B K$ dan menyediakan GPK, namun untuk fasilitas khusus sekolah inklusi yang lain pada sekolah tersebut tiak memadai.

Guru pendamping khusus (GPK) adalah guru yang mempunyai latar belakang pendidikan khusus (pendidikan luar biasa) ataupun guru yang mendapat pelatihan tentang pendidikan khusus (luar biasa) yang ditugaskan di sekolah inklusi (Garnida, 2015). Sekolah inklusi harus menyediakan guru khusus anak berkebutuhan khusus atau guru pendamping. Guru pendamping yang khusus menghadapi anak bekebutuhan khusus yang berperan dalam membimbing anak berkebutuhan khusus dalam proses belajar yang sudah dituntun oleh kurikulum sekolah. Ketika sekolah inklusi tidak dapat menyediakan guru pendamping khusus anak berkebutuhan khusus, maka guru pelajaran lainnya akan sulit dalam menghadapi murid-muridnya.

Guru yang mengajar disekolah inklusi memiliki tuntutan yang berbeda dengan guru yang mengajar di sekolah umumnya. Guru yang mengajar di sekolah inklusi dituntut untuk dapat mengelola iklim kelas agar siswa regular tidak merasa terganggu atas keberadaan ABK didalam kelasnya dengan dibantu oleh guru pendamping (Ni'matuzahroh, 2015). Guru di sekolah inklusi memiliki tuntutan dalam mengajar anak berkebutuhan khusus ( $A B K$ ) yang digabungkan dengan anak yang tidak berkebutuhan khusus (Non ABK). Guru di sekolah inklusi dituntut untuk mengajar dan meningkatkan kemampuan anak berkebutuhan khusus. Sejalan dengan karakteristik pendidikan inklusi Budiyanto (2017) menjelaskan bahwa pendidikan inklusi berarti menyiapkan dan mendorong guru untuk mengajar secara interaktif. perubahan dalam kurikulum berkaitan erat dengan perubahan secara metode pembelajaran.

Kurangnya kesiapan yang dilakukan sekolah inklusi berdampak kepada kesiapan guru yang mengajar di sekolah inklusi. Hasil observasi dan wawancara yang di lakukan peneliti pada 21-25 oktober 2019 dimana terdapat fenomena yang terlihat disalah satu sekolah inklusi memperlihatkan guru yang tidak mengerti bagaimana $A B K$ atau anak berkebutuhan khusus, mereka juga menunjukkan sikap bingung dalam menghadapi anak ABK saat tantrum atau pun saat mengajak untuk belajar. Guru yang mengajar menuntut anak berkebutuhan khusus memiliki kemampuan yang sama atau yang tidak jauh dari anak yang tidak berkebutuhan khusus lainnya yang ada di kelas. Tidak jarang juga anak bekebutuhan khusus tersebut ditegur atau dimarahi ketika tidak mengikuti intruksi atau tidak mampu mengikuti proses pembelajaran.

Hasil survey yang dilakukan kepada 38 guru di beberapa sekolah inklusi di Pekanbaru yang dilakukan pada tanggal 19 - 23 Maret 2020 dengan menitipkan kepada perwakilan guru didapat bahwa dalam menjalankan perannya mengajar ABK ditemukan $47,36 \%$ guru yang 
menunjukkan kondisi emosi negatif yaitu $13,16 \%$ guru yang merasa bingung bagaimana cara menghadapi ABK, 7,89\% merasa terganggu, $10,53 \%$ merasa galau dan $15,8 \%$ merasa sulit dan repot karena tidak lengkapnya fasilitas untuk proses belajar di sekolah tersebut. Meskipun demikian, ada $34,22 \%$ merasa biasa saja (netral) dan $18,42 \%$ guru yang merespon dengan kondisi emosi positif yaitu 13,16\% guru yang mengajar di sekolah inklusi merasa senang atau merasa tidak terganggu, 5,26\% menjadikan mengajar ABK menjadi pengalaman yang baru. Ini menunjukkan bahwa sebagian besar guru menunjukkan emosi negatif dalam mengajar ABK di sekolah inklusi.

Kesimpulannya bahwa sebagian besar guru SD inklusi merasa repot atau kesulitan saat mengahadapi ABK, guru SD inklusi juga sangat membutuhkan pengetahuan dan fasilitas untuk $A B K$ yang menjadi permasalahan timbulnya indikasi merasa terbeban dan akhirnya menjadi sumber stress kerja yang berasal dari emosi ataupun sikap yang ditunjukkan pada guru SD inklusi.

Sejalan dengan penelitian yang dilakukan oleh Nursuciati dan Supradewi (2014) yang menjelaskan hasil penelitiannya guru SLB yang memiliki stress kerja yang tinggi maka memiliki penyesuaian diri yang rendah. Hal ini didukung oleh penjelasan Daradjat (2016) yang menjelaskan bahwa kesehatan mental adalah suatu kondisi seseorang yang mampu menyesuaikan dirinya di lingkungan sekitar. Artinya guru yang memiliki penyesuaian dirinya rendah, maka berpengaruh terhadap kesehatan mentalnya.

Sehat mental yang di jelaskan oleh Menninger (dalam Yusuf, 2018), juga menjelaskan bahwa kesehatan mental adalah suatu kondisi dimana seseorang dapat menyesuaikan diri terhadap lingkungannya dan orang lain, dan menunjukkan kebahagiaan yang optimal. Hal ini menunjukkan bahwa ketika guru mengalami kesulitan dalam beradaptasi, kekurangan fasilitas dalam mengajar dan memiliki tekanan-tekanan dalam stress kerja, maka dapat berpengaruh terhadap kesehatan mental pada guru.

Viet dan Ware (dalam Faizah \& Amnah, 2016) menjelaskan orang yang memiliki kesehatan mental adalah suatu kondisi individu yang tidak hanya dilihat berdasarkan ada tidaknya simptom-simtom tekanan psikologis yang muncul, tetapi juga berkaitan dengan adanya karakteristik kesejahtraan psikologis yang berpengaruh dalam hidupnya seperti perasaan gembira, tertarik dan dapat menikmati hidup yang dijalaninya.

Berdasarkan uraian situasi yang dihadapi guru di sekolah inklusi diatas, maka penulis tertarik untuk membahas tentang bagaimana kesehatan mental guru di sekolah inklusi dengan judul "Gambaran Kesehatan Mental Pada Guru Sekolah Dasar (SD) Inklusi di Pekanbaru".

\section{Tinjauan Teori: Kesehatan Mental Pengertian Kesehatan Mental}

Menninger (dalam Yusuf, 2018), mendefinisikan sehat mental sebagai suatu dimana manusia dapat menyesuaikan diri terhadap lingkungannya dan orang-orang di sekitarnya secara efektif dan menunjukkan kebahagiaan yang optimal. Tidak sekedar efesiensi dan kegembiraan atau ketaatan, dalam mental yang sehat terdapat kemampuan untuk memelihara watak inteligensi yang siap untuk digunakan, perilaku yang dipertimbangkan secara sosial, dan disposisi yang bahagia.

Daradjat (2016) juga menjelaskan bahwa kesehatan mental adalah kemampuan untuk menyesuaikan diri dengan diri sendiri, dengan orang lain dan masyarakat serta lingkungan di mana ia hidup serta terhindarnya orang dari gejalagejala gangguan jiwa (neurose) dan dari gejala-gejala penyakit jiwa (psychose). Dari penjelasannya orang yang sehat mental adalah orang yang terhindar dari gejala-gejala penyakit jiwa dan mampu menyesuaikan dirinya dengan lingkungan masyarakat.

Kesehatan mental yang dijelaskan oleh Kartono (2000) juga menjelaskan bahwa kesehatan mental juga suatu kondisi individu yang dapat meneyesuaikan dirinya, dapat memecahkan masalah. 
Kartono menambahkan bahwa kesehatan mental yaitu adanya kesanggupan individu atas tugas dan tangguang jawab sosial dan dapat menerima realitas kehidupan.

Kesehatan mental menurut The World Federation for Mental Health, adalah suatu kondisi yang memungkinkan perkembangan optimal bagi individu secara fisik, intelektualdan emosional sepanjang hal itu tidak bertentangan dengan kepentingan orang lain. Sedang kan menurut undang-Undang kesehatan mental momor 3 tahun 1966 kesehatan mental menurut paham ilmu kedokteran adalah suatu kondisi yang memungkinkan perkembangan fisik, intelektual dan emosional dari seseorang dan perkembangan itu berjalan selaras dengan keadaan orang-orang lain. Maka kesehatan mental mempunyapunyai sifatsifat yang humoris (serasi) dan memperhatikan semua segi-segi dalam penghidupan manusia dan dalam hubungan dengan manusia (dalam Hidayat \& Hardi, 2013)

Kesehatan mental yang dijelaskan oleh Viet dan Ware (dalam Faizah \& Amnah, 2016) adalah suatu kondisi individu yang tidak hanya dilihat berdasarkan ada tidaknya simptom-simtom tekanan psikologis yang muncul, tetapi juga berkaitan dengan adanya karakteristik kesejahtraan psikologis yang berpengaruh dalam hidupnya seperti perasaan gembira, tertarik dan dapat menikmati hidup yang dijalaninya.

\section{Dimensi Kesehatan Mental}

Menurut Veit dan Ware (dalam Faizah \& Amnah, 2016) dimensi kesehatan mental terdiri atas:

a. Psychological Well-Being, yaitu suatu kondisi individu yang dapat menjelaskan efek posotif yang berkaitan dengan kesehatan mental dalam diri individu. Psychological well-being terbagi dalam dua subdimensi yaitu, efek positif secara umum (general positive affect) dan ikatan emosi (emotion ties).

b. Psychological Distress, yaitu suatu kondisi individu yang dapat menjelaskan efek negatif yang berkaitan dengan kesehatan mental dalam diri individu.
Psychological distress terbagi dalam tiga subdimensi yaitu, kecemasan (anxiety), depresi (depression) dan kehilangan control perilaku atau emosi (lass of behavioural / emotion control).

\section{Karakteristik Mental yang Sehat}

Yusuf (2018) menjelaskan karakteristik individu yang memiliki sehat mentalnya memiliki 4 karakteristik, yaitu :

a. Kematangan Emosi, orang yang memiliki kematangan emosi memperlihatkan tida ciri perilaku yaitu, memiliki kemandirian, meiliki disiplin diri dan determinasi diri.

b. Kemampuan menerima realitas, adanya perbedaan antara keinginan, dorongan, dan ambisi seseorang serta peluang ken kemampuan seseorang lainnya adalah hal yang bias saja terjadi. Seseorang yang memiliki kemampuan untuk menerima realitas akan memperlihatkan perilaku mampu memecahkan masalah dengan segera dan menerima tanggung jawab.

c. Dapat hidup bersama dan dapat bekerja sama dengan ornag lain. Hal ini menyangkut hakikat dirinya sebagai makhluk social yang tidak sekedar bersedia dan mau bekerja sama untuk mencapai tujuan yang tinggi.

d. Memiliki filsafat atau pandangan hidup. Seseorang memiliki pandangan hidup senantiasa dapat terbimbing untuk dalam menjalankan kehidupan, terutama saat menghadapi situasi yang menggnggu dan menjadi beban.

\section{Faktor yang mempengaruhi kesehatan mental}

Yusuf (2018) menjelaskan ada 3 faktor yang mempengaruhi kesehatan mental seseorang, yaitu:

a. Faktor Biologi

Faktor biologi dapat mempengaruhi kesehatan mental seseornag seperti, genetik, ketidak seimbangan kimiawi dalam tubuh, menderita penyakit kronis, dan kerusakan system saraf pusat.

b. Faktor Psikologis

Faktor psikologi seperti, frustrasi (merasa kecewa ataupun sedih) terjadinya konflik, tidak mendapatkan 
kasih sayang, terlalu pesimis menghadapi masa depan, dan kurang mendapat pengakuan dari kelompok.

c. Faktor lingkungan

Faktor lingkungan seperti, lingkungan tempat tinggal atau pun lingkungan kerja yang dapat memicu timbulnya stress yang akan mempengaruhi kesehatan mental.

\section{METODE PENELITIAN}

Penelitian ini merupakan deskriptif kuantitatif. Penelitian ini menggunakan teknik penggambilan sampel, Cluster dimana di dapat jumlah subjek penelitian sebanyak 182 orang guru di sekolah dasar inklusi Pekanbaru.

Alat ukur yang digunakan dalam penelitian ini skala yang di adptasi oleh Faizah dan Amna (2016) yaitu Health inventory-38 mengandung dua dimensi, yaitu : Psychological well-being ini meliputi 3 subdimensi yaitu pengaruh umum yang positif, ikatan emosional dan kepuasan hidup . dan Psychological distress ini meliputi 3 subdimensi yaitu kecemasan, depresi dan hilangnya kontrol emosi.

\section{HASIL DAN PEMBAHASAN}

Berdasarkan hasil analisis deskriptif, diketahui bahwa secara umum indeks kesehatan mental guru-guru SD inklusi di Pekanbaru mayoritas berada pada kategori sedang yaitu 77 orang denga persentase $42,3 \%$. Uraian lengkap indeks kesehatan mental guru SD Inklusi dapat dilihat pada gambar 4.1 berikut ini:

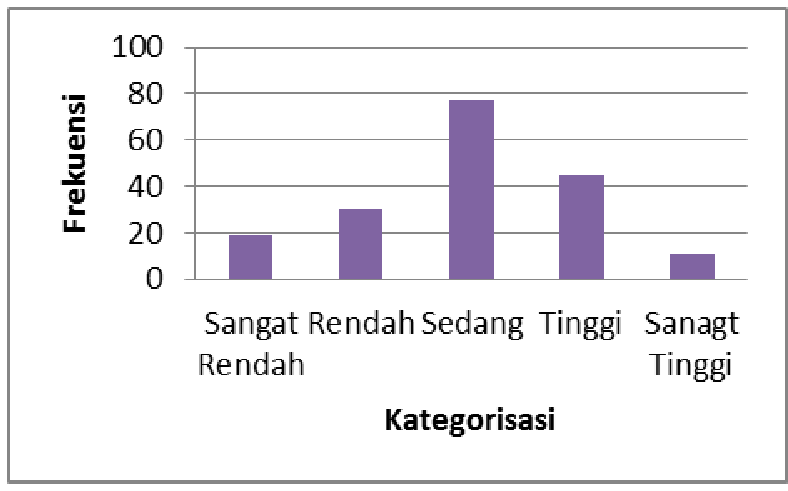

Gambar 1

Histogram Kesehatan Mental Guru SD Inklusi di Pekanbaru
Tabel 1 Gambaran Psychological Wellbeing

\begin{tabular}{cccc}
\hline Kategori & Skor & Frekluensi & Persentase \\
\hline Sangat Tinggi & $X>79,22$ & 13 & $7,1 \%$ \\
Tinggi & $65,83>\mathbb{X} \leq 79,22$ & 49 & $24,2 \%$ \\
Sedang & $52,46 \leq X \leq 65,83$ & 63 & $34,6 \%$ \\
Rendah & $39,07 \leq X \leq 52,46$ & 44 & $26,9 \%$ \\
Sangat Rendah & $X<39,07$ & 13 & $7,1 \%$ \\
Jumlah & & 182 & $100 \%$ \\
\hline
\end{tabular}

Berdasarkan tabel diatas dapat disimpulkan bahwa psychological weelbeing dari 182 guru SD inklusi di Pekanbaru paling tinggi pada kategori sedang berjumlah 63 orang atau $34,6 \%$. Jika dibandingkan antara skor kategori tinggi dan lebih rendah, lebih banyak pada skor dengan ketegori rendah yaitu 26,9\% sedangkan yang skor kategori tinggi

\begin{tabular}{cccc}
\hline Kategori & Skor & Frekuensi & Persentase \\
\hline Sangat Tingi & $\mathrm{x}>79,22$ & 14 & $7,7 \%$ \\
Tinggi & $65,83>x \leq 79,22$ & 38 & $20,9 \%$ \\
Sedang & $52,46 \leq x \leq 65,83$ & 84 & $46,2 \%$ \\
Rendah & $39,07 \leq \mathrm{x} \leq 52,46$ & 32 & $17,0 \%$ \\
Sangat Rendah & $X<39,07$ & 14 & $7,7 \%$ \\
Jumlah & & 182 & $100 \%$ \\
\hline
\end{tabular}

$24,2 \%$.

Tabel 2 Gambaran Psychological Distress

Berdasarkan tabel diatas dapat disimpulkan bahwa psychological distress dari 182 guru SD inklusi di Pekanbaru paling tinggi pada kategori sedang berjumlah 84 orang atau 46,2\%. Jika dibandingkan antara skor kategori tinggi dan skor kategori rendah, lebih banyak pada skor kategori tinggi 20,9\%, sedangkan skor kategori rendah hanya $17,6 \%$.

\section{PEMBAHASAN}

Dalam penelitian ini menggambarkan hasil kesehatan mental guru SD inklusi di Pekanbaru dengan subjek 182 orang guru menunjukkan hasil pada 77 orang guru 
termasuk dalam kategori sedang dengan persentase $42,3 \%$. Artinya guru SD inklusi sebagian besar memiliki kesehatan mental yang sedang dimana berarti guru SD inklusi dapat menyesuaikan diri, dapat memecahkan masalahnya dan dapat melaksanakan tugas dan tanggung jawabnya di kategori sedang.

Menninger (dalam Yusuf, 2018) yang menjelaskan bahwa sehat mental itu adalah suatu kondisi individu yang berhasil dan dapat menyesuaikan dirinya terhadap lingkungan sekitarnya, dan kemudian mendapatkan suatu kebahagiaan yang optimal dan menghasilkan perilaku sosial yang bahagia. Seseorang yang berhasil melakukan penyesuaian terhadap lingkungan sekitarnya akan memperlihatkan perilaku yang nyaman, taat dan tetap mempertahankan. Kesehatan mental yang di jelaskan Kartono (2000) yang menambahkan sehat mental itu ialah suatu kondisi seseorang yang berhasil melakukan penyesuaian dan dapat memecahkan masalah dalam kehidupan dan dapat melakukan tugas dan tanggung jawab sosialnya.

Dari hasil penelitian didapat bahwa, kesehatan mental guru SD inklusi di pekanbaru dengan jumlah subjk 182 orang guru, sebagian besarnya memiliki kesehatan mental yang sedang. Guru dapat melakukan penyesuaian diri dan kemudian guru mendapatkan kebahagiaan yang optimal, guru dapat memecahkan masalah dan guru dapat melaksanakan tugas dan tanggung jawabnya.

Kesehatan mental yang dijelaskan Viet dan Ware (1983) memiliki aspek psychological well-being dan psychological disstres. Dari hasil penelitian gambaran psychological well-being pada guru SD inklusi di Pekanbaru terdapat pada kategori sedang, artinya guru SD inklusi sebagian besarnya dapat merasakan perasaan positif secara umum, kondisi emosional yang sedang, dan merasakan kepuasan hidup.

Psychological well-being yang ditinjau dari beberapa aspek diantaranya berdasarkan jenis kelamin yaitu berada pada kategori sedang, begitupula jika ditinjau berdasarkan usia, psychological well-being di SD inklusi juga berada pada kategori sedang, Adapun jika ditinjau berdasarkan lama mengajar psychological well-being guru sd inklusi juga tergolong sedang dan jika ditinjau berdasarkan status guru honorer, PNS maupun pegawai juga berada pada kategori sedang, serta jika ditinjau berdasarkan status guru yang mengajar sebagai wali kelas, guru mata pelajaran dan guru pembimbing khusus juga berada pada kategori sedang, artinya psychological well-being guru pada SD inklusi ditinjau dari beberapa aspek menunjukkan kategori sedang tidak berada pada kategori tinggi dan maupun rendah. Psycological well being atau di sebut dengan kesejahteraan psikologi adalah suatu kondisi dimana seseorang menjalin hubungan positif dengan orang lain, memiliki tujuan hidup dan kondisi emosional yang di alami oleh seseorang (Isnawati \& Yunita, 2019).

Untuk psychological distress dalam penelitian ini didapat bahwa, psychological distress pada guru SD inklusi sebagian besar guru memiliki psychological distress yang sedang. Adapun jika ditinjau berdasarkan lama mengajar Psychological distress guru sd inklusi juga tergolong sedang dan jika ditinjau berdasarkan status guru honorer, PNS maupun pegawai juga berada pada kategori sedang, serta jika ditinjau berdasarkan status guru yang mengajar sebagai wali kelas, guru mata pelajaran dan guru pembimbing khusus juga berada pada kategori sedang, namun berbeda jika dilihat dari guru pembimbing khusus yang mana $50 \%$ menunjukkan kategori sedang dan $50 \%$ berada pada kategori sangat tinggi.

Artinya secara keseluruhan bahwa psychological distress guru pada SD inklusi ditinjau dari beberapa aspek menunjukkan kategori sedang tidak berada pada kategori tinggi dan maupun rendah Psychological distress yang dijelakan oleh Candra, dkk (2017) adalah suatu perasaan dimana seseorang merasakan taku, khawatir dan cemas yang dimana respon normal terhadap suatu kejadian yang mengancam. distres juga di jelaskan sebagai respon pengaruh negatif yang di 
munculkan oleh seseorang dari stresor atau penyebab stresnya.

\section{SIMPULAN}

Hasil dari penelitian ini menunjukkan gambaran kesehatan mental guru SD inklusi yang ada di Pekanbaru, dari 182 orang guru sebagian besar guru SD inklusi memiliki kesehatan mental yang sedang. Untuk psychological well-being dan psychological distress pada guru SD di kategori sedang.

\section{DAFTAR PUSTAKA}

Amalia, Whyuni, \& Ekawati. (2017). Hubungan Antara Karakteristik Individu, Beban Kerja Mental, Pengembangan Karir Dan Hubungan Interpersonal Dengan Stress Kerja Pada Guru Di SLB Negeri Semarang. Jurnal Kesehatan Masyarakat (e-Journal). 5(5). 68-78. Diunduh dari: https://ejournal3.undip.ac.id/index.php/jk m/article/view/18870.

Azwar, S. (2017). Dasar-dasar Psikometrika Edisi II. Yogyakarta: Pustaka Pelajar.

Budiyanto, M. Pd, Dr. (2017). Pengantar Pendidikan Inklusif Berbasis Budaya Lokal. Surabaya: Prenadamedia Group.

Bungin, B. (2011). Metodologi Penelitian Kuantitatif. Jakarta: kencana.

Candra, dkk. (2017). Psikologi Landasan Keilmuan Praktik Keperawatan Jiwa. Yogyakarta: ANDI

Daradjat, Dr. Zakiah. (2016). Kesehatan Mental. Jakarta: PT. Gunung Agung.

Faizah \& Amnah. (2016). Hubungan Antara Bullying Dengan Kesehatan Mental Pada Remaja Sekolah Menengah Atas Di Banda Aceh. [Skripsi]. Fakultas Kedokteran Universitas Syiah Kuala.

Garnida, M. Pd, , Dr. Dadang. (2015). Pengantar Pendidikan Inklusif. Bandung: Refika Aditama.

Gholamittooranposhti, Marzieh. (2012). International Conference on Education and Educational Psyvhology (ICEEPSY 2012) Teacher' Mental health. Procedia - Social and Behavioral Sciences, 69,
1295-1301. Diunduh dari: https://www.sciencedirect.com/science/ article/pii/S1877042812055255

Grosy, Chanderkant, dkk. (2015). Mental Health among Government School Teachers. The International Journal of Indian Psychology. 3. 117-124. Diunduh dari: https://www.researchgate.net/publicatio n/292154656 Mental Health among G overnment School Teachers/link/56ab6 91d08aed814bdea168c/download.

Hadi, S. (2004). Metodologi Research (jilid 1). Yogyakarta: Andi Offset

Hidayat, M.Psi dan Herdi, M.Psi. (2013). Bimbingan Konseling Kesehatan Mental di Sekolah. Jakarta: PT. Remaja Rosdakarya.

Ifdil. (2018). Mengembangkan Kesehatan Mental di Lingkungan Keluarga dan Sekolah. Journal of Innvative Counseling: Theory, Practice \& Research, 2(2): pp.1-9. Diunduh dari: https://www.journal.umtas.ac.id/index.ph p/innovative counseling/article/view/248

Isnawati \& Yunita. (2019). Buku Ajar Konsep Pembentukan Kader Kesehatan Jiwa Di Masyarakat. Sulawesi: Yayasan Ahmar Cendikia Indonesia

Kartono, DR. Kartini. (2000). Hygiene Mental. Bandung: Mandar Maju.

Meiza, Chairani. (2016). Perbedaan Kebahagiaan Pada Guru Berstatus PNS Dan Honorer. Jurnal Ilmiah Psikologi. 9(2). 132-141. Diunduh dari:https://ejournal.gunadarma.ac.id/ind ex.php/psiko/article/view/1551.

Mustika, Zahara. (2015). Pentingnya Peranan Wali Kelas Dalam Pembelajaran. Intelektuali. 3(1). 65-78. Diunduh dari : https://www.jurnal.arraniry.ac.id/index.php/intel/article/view/2 $00 / 181$.

Mohana, Dr.D. (2013). A Study Related to Mental of Teachers with Reference to Level of Teaching and Teaching Experience. IOSR Journal of Research \& Method in Education (IOSR- JRME. 1(5). PP 61-63. Diunduh dari: https://www.iosrjournals.org/iosrirme/papers/Vol-1\%20lssue5/J0156163.pdf?id=1700. 
Nursucianti \& Supradewi. (2014). Hubungan Antara Stres Kerja Dengan Penyesuaian Diri Pada Guru SLB Di Lingkungan Kerjanya. (2). 75-90. Diunduh dari: http://lppmunissula.com/jurnal.unissula.ac.id/index. php/proyeksi/article/view/3303

Purnomo, Edi. (2016). Kebutuhan Guru Sekolah Dasar Inklusi dalam Meningkatkan Kompetensi Melalui Media Video. Kwangsan, Vol. 4 No. 2. 95-104. Diunduh dari: https://www.neliti.com/publications/2869 08/kebutuhan-guru-sekolah-dasarinklusi-dalam-meningkatkankompetensi-melalui-media.

Ramayulis. (2013). Psikologi agama. Jakarta: Radar Jaya Offset Jakarta.

Subandi, M.A. (2019). Psikologi Agama \& Kesehatan Mental. Yogyakarta: Pustaka Belajar.
Sugiyono. (2011). Statistika untuk penelitian. Bandung. Alfabeta.

Wardhani, Rr. Dina Kusuma. (2017). Peran Kesehatan Mental Bagi Guru Dalam Proses Belajar Mengajar di Sekolah. Prosiding Seminar Nasional Pendidikan FKIP UNTIRTA. 193-198. Diunduh dari : http://150.107.142.250/index.php/psnp/a rticle/view/193-198.

Yusuf L.N, Prof. Dr. Syamsu. (2018). Kesehatan Mental Perspektif Psikologi dan Agama. Bandung: PT Remaja Rosdakarya.

Veit, C.T., \& Ware, J. E. (1983). The structure of psychological distress and well-being in general populations. Journal of Consulting and Clinical Psychology, 51, 730-742. Diunduh dari: http://psycnet.apa.org/record/198402935-001. 
Volume 1, No.1, Juni 2021 